Paideusis

\title{
Barking up the Wrong Tree: A Response to Dennis Cato's "Talking to the Animals"
}

\section{Daniel Vokey}

Volume 14, Number 2, 2001

URI: https://id.erudit.org/iderudit/1072800ar

DOI: https://doi.org/10.7202/1072800ar

See table of contents

Publisher(s)

Canadian Philosophy of Education Society

ISSN

0838-4517 (print)

1916-0348 (digital)

Explore this journal

Cite this document

Vokey, D. (2001). Barking up the Wrong Tree: A Response to Dennis Cato's

"Talking to the Animals". Paideusis, 14(2), 66-71.

https://doi.org/10.7202/1072800ar

This document is protected by copyright law. Use of the services of Erudit (including reproduction) is subject to its terms and conditions, which can be viewed online.

https://apropos.erudit.org/en/users/policy-on-use/
This article is disseminated and preserved by Érudit.

Érudit is a non-profit inter-university consortium of the Université de Montréal, Université Laval, and the Université du Québec à Montréal. Its mission is to promote and disseminate research.

https://www.erudit.org/en/ 


\section{Barking up the Wrong Tree: A Response to Dennis Cato's "Talking to the Animals"}

\section{Daniel Vokey, University of Prince Edward Island}

In his review of my article "Longing to Connect: Spirituality in Public Schools" (Vokey, Paideusis 13: 2, 2000), Dennis Cato asserts that teachers would be justified in greeting its contents with deep suspicion-the kind of suspicion with which they typically greet "the deliverances of educationalists which attempt to prescribe classroom content or practice" (Cato, Paideusis 14: 1, 2001, p. 56). What teachers are expected to be suspicious of is not clear: Cato doesn't say. What is clear is that he imagines a suspicious response to the article is justified because he believes that it was written both to convince classroom teachers they should integrate spirituality into their curricula and to provide direction for those teachers who undertake to do so. However, my article does not recommend to teachers that they embrace my or any other particular vision of what spirituality might look like in schools. The stated intent of my article, as Cato himself observes, is to "discuss in very general terms the prospects for success of proposals to incorporate spirituality within public school curricula." Because my article was clearly not written "to prescribe classroom content or practice," Cato's concern on this front is misplaced: he is simply barking up the wrong tree. And, alas, not for the last time. Cato fails to justify the suspicious response he imagines my article will provoke because, as I will show below, he consistently misrepresents its claims and its intent.

\section{What will spirituality offer students and teachers?}

The first section of my article summarizes my understanding of what advocates of spirituality in schools believe its benefits would be. The section concludes with the statement that, "if there is one over-arching theme in the literature on spirituality in education, it is that of connection. .." (Vokey, 2000, p. 27). In responding to this section of my article, Cato misrepresents it as embracing and endorsing the beliefs and enthusiasms of the authors whose works are reviewed. He then identifies a problem with my alleged ambition to see spirituality in classrooms. The problem is that, in saying "spirituality is typically presented as consisting of, or leading to, student experiences of connectedness ..." (Vokey, 2000, p. 27), I am providing no account of what teachers could do to foster such experiences. Cato remarks that spirituality cannot at the same time both lead to and consist of experiences of connectedness, for that would require that spirituality be its own cause. Logically 
speaking, it has to be one or the other. His basic complaint is that, whichever option I choose, I say nothing pedagogically useful by simply listing the potential benefits of "experiences of connectedness" because such a list provides no description of what one could do to become connected (Cato, 2001, p. 57).

Cato is correct is observing that the first section of my article does not define spirituality in a way that would provide guidance to those who wished to promote it in classrooms. Of course, it is not possible to provide a single definition of what spirituality means to those advocating its inclusion in schools because, as even my brief survey illustrates, the word means different things in different contexts. Neither is it possible to characterize spirituality by describing the kinds of activities one might recommend to schools because the various kinds of connectedness described in the literature can be fostered by a wide variety of practices-including, in some traditions at least, talking to the animals. Cato would have been correct in seeing this as a problem with my article if its goal were to implement the recommendations it surveys rather than summarize them. Instead, that the meaning of the term can vary from context to context simply reinforces the claim advanced later in the article that spirituality is not so tradition-independent as its advocates sometimes suppose. Indeed, Cato (2001, p.57) oversimplifies the matter when he states that "for Vokey to say that spirituality 'is typically presented as consisting of, or leading to, student experiences of connectedness' is to say either that spirituality is identical to, or the cause of, connectedness but the two claims are mutually exclusive." This statement overlooks the fact that word spirituality, like the word faith, can in some contexts refer to a particular kind of path, and in other contexts refer to the goal or fruition of that path. Because the meaning of the term can vary according to context, there is no necessary contradiction involved in observing that spirituality is sometimes presented as leading to, and other times presented as consisting of, experiences of connectedness.

\section{Obstacles to Integrating Spirituality within Public School Curricula}

The second section of my article argues that certain general features of our current social, cultural, political, and economic context represent three serious obstacles to any attempt to integrate spirituality within public school curricula, even granted considerable variation among the initiatives proposed. In shortest form, the first such obstacle is that, "because we disagree on the nature of human potential and on the means of its realization, we lack consensus on the substantive criteria of genuine human development that responsible public education in spirituality would require" (Vokey, 2000, p. 29). This statement rests upon a number of claims and 
arguments, some of which (judging from his parenthetical comments) Cato finds puzzling or otherwise difficult to accept. However, he offers no sustained analysis of or counter-arguments to my claims, so it is difficult to ascertain the exact nature of his suspicions-particularly since he himself makes the similar point that, if the concept spirituality is to have any "pedagogical purpose," then an account of how to foster one or another form of connection is required.

It is true that many of the arguments in my article are presented in very abbreviated form. "Longing to Connect" is based upon a paper presented at the Annual Conference of the Canadian Society for Studies in Education in one of the sessions sponsored by the Canadian Philosophy of Education Society. I must take responsibility for not more carefully revising the paper with a broader audience in mind before submitting it to Paideusis. In particular, the article should provide more references to publications elaborating and supporting the points that are important to its arguments and conclusions. Here, then, by way of small recompense, is a reference to a more thorough treatment of the claims (a) that the mechanistic world view is, scientifically speaking, out of date; (b) that the substantive criteria of genuine human development required for responsible spiritual education are internal to the points of view of the communities and corresponding historical traditions of moral inquiry and practice, and (c) that the pluralism of such traditions presents a yet-unresolved dilemma to public education in liberal democracies.

The second obstacle the article identifies to implementing proposals to bring spirituality into public education is that, even if a rationally defensible and pedagogically sound program of spiritual development were formulated that proved acceptable to the diverse members of our pluralistic societies, there is still no guarantee that the program's objectives would be embraced by those who establish the curricula of public schools, who may have other priorities. To drive home this point my article observes that, even if we could demonstrate that spiritual education is in the best interests of public school students, this would accomplish little if serving the needs of its students are not what public schools are really for. It then cites three authors with similar concerns about the compatibility of spiritual education with the bureaucratic organization of modern public school systems. Here, Cato again misrepresents the intent of my article, in this case by stating that it includes the three quotes to "prove" its concerns are justified. Again, he provides no counter-arguments or evidence, in this case to support his incredulous reactions to my claims. Indeed, I fail to see how Cato's mock astonishment at the suggestion that public school priorities are hotly contested is consistent with his evident distrust of the directives of "educationalists" that supposedly impose agendas on schools. In 
any event, even if we assume that all the stakeholders in public education have the best interests of students at heart, it remains both that deep-rooted disagreement persists on a wide range of educational policy issues and that no clear mechanism exists to ensure that government decisions on those issues are held accountable to public rational debate.

The third obstacle my article identifies to the implementation of one or another form of spiritual education in public schools is that "it is not clear who would educate, or even be qualified to hire, the trustworthy spiritual mentors and guides that even ad hoc educational initiatives would require (Vokey, 2000, p. 33). Here, Cato dedicates a single sentence to consideration of the reasoning behind this concern, and offers no evidence or counter-arguments to show that the concern is unfounded. The grounds for a suspicious response to the article remain unclear.

\section{So What to Do?}

It is much easier, of course, to point out potential problems than to provide solutions. My first draft of "Longing to Connect" stopped at the end of the previous section precisely for that reason. I added the third section to the article because, however pessimistic I am about their short-term prospects, I am sympathetic to many of the proposals for encouraging forms of "connectedness" that have been put forward by advocates of spirituality in public schools. The third section of my article offers what I hope are constructive suggestions to those who are both interested in the possibility that some form of spirituality might eventually become part of public school curricula and concerned about the general features of our social context that my article briefly describes.

The first recommendation is that representatives of competing points of view engage in critical dialogue to discover and create common ground, with the ultimate aim of arriving at greater consensus on the nature and conditions of genuine spiritual development. Cato has a number of difficulties with this project. He is unconvinced by the reasoning that, if lack of consensus is an obstacle to some proposed course of action, then it makes sense to at least attempt to reach greater agreement across differences. He is unable to imagine how progress towards consensus would be possible if those who came to the table shared the epistemological assumptions that my article recommends. There are no guarantees, of course, that efforts to reach consensus will bear fruit even under ideal conditions. At the same time, it seems reasonable to suppose that the chances of dialogue resulting in agreement will be improved if those who participate neither reject the possibility of truth out of hand (the radical relativist position) nor insist that they 
already have the truth, the whole truth, and nothing but. Similarly, it seems reasonable to suppose that such dialogue would have to aim at a characterization of spirituality at once narrow enough to have pedagogical purchase and yet broad enough to encompass insights from multiple perspectives.

If and when advocates of spirituality in public schools achieve consensus on the nature and conditions of genuine spiritual development, through critical dialogue or otherwise, they are still faced with the challenge of effecting whatever changes to current school priorities and practices would be required to add spiritual growth to an already long list of desired educational outcomes. The article's second recommendation is that those seeking to effect such changes consider (a) capitalizing upon the interest in reform that is created when there is perceived to be too large a gap between what public schools promise and what they deliver; and (b) ensuring that successful pilot programs or alternative schools exist that could demonstrate the feasibility and benefits of any innovations proposed. Of course, no changes to public schools are likely to be of real benefit to students if teachers are not convinced of the merits of the changes or are not provided the support they need to translate vision into reality. This point brings us back to the question of who would be qualified to educate or hire the spiritual mentors needed to guide students in their spiritual development. My article's third recommendation-made principally for my own benefit, I must confess, as I hoped I would take my own advice-is essentially that teacher educators wishing to promote the spiritual development of others must attend to their own disciplines of spiritual study and practice as the necessary first step.

In his review of its recommendations, Cato again misrepresents my article's intent, here by describing as "both swift and bold" suggestions that are explicitly cautious and qualified. By the sarcastic tone of his remarks I gather that Cato finds little merit in the recommendations. Whether this is because he finds them simplistic, unworkable, or both is not clear: again, Cato doesn't say. Instead, he concludes his review by reiterating his earlier point that undertaking spiritual study and practice requires a knowledge of some particular spiritual discipline that my article does not provide. Here, as before, I fail to see how this justifies suspicion of my analysis and recommendations given that programs introducing one or more spiritual traditions are widely available today, and it was no part of the intent of my article to champion one in particular. The challenge I see facing teachers and teacher educators seeking to deepen their own spirituality is less a lack of knowledge or guidance than a lack of support from institutions that do not recognize spiritual practice as a form of professional development. 
Dennis Cato's review of "Longing to Connect," if I interpret it correctly, was written to discredit what he takes to be an ill-conceived attempt to tell teachers what to do. I hope this response has reassured him that his worries are misplaced. Whether or not his suspicious response to the original article was justified I leave to the readers of Paideusis to decide.

\section{References}

Cato, Dennis. (2002). Talking to the animals: Daniel Vokey and introducing spirituality into public schools. Paideusis 14: 1, 2001, 56-60.

Halford, Joan M. (1998). Longing for the sacred in schools: A conversation with Nel Noddings. Educational Leadership, 56(4), 28-32.

Mulcahy, Dennis M. (1999). Critical perspectives on rural education reform.

Palmer, Parker J. (1998) Evoking the spirit in public education. Educational Leadership, 56 (4), 6-11.

Vokey, Daniel. (2000). Longing to connect: Spirituality in Public Schools. Paideusis, 13(2), $23-41$.

Vokey, Daniel. (2001). Moral discourse in a pluralistic world. Notre Dame: University of Notre Dame Press.

Weaver II, R. L. and Cotrell, H. W. (1992). A non-religious spirituality that causes students to clarify their values and to respond with passion. Education, 112(3), 426-436. 